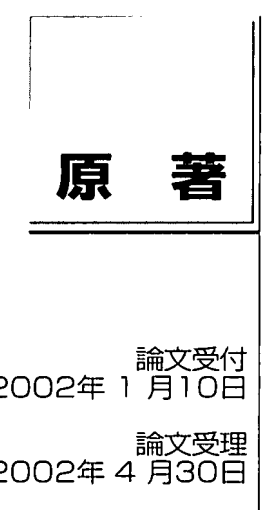

Code No. 853

\section{アプリケータのない電子線照射野の \\ 軸外平均入射エネルギーの测定：シンチレーション \\ ファイバ電子線エネルギーモニタの利用}

\author{
青山裕一・小山修司 ${ }^{1)}$
}

名古屋大学医学部附属病院放射線部

1 ) 名古屋大学医学部保健学科放射線技術科学専攻

\section{緒 启}

高エネルギー電子線の治療は，おもに裴在性の悪性 腫瘍の治療に用いられるが，そのなかには皮境に発生 する琹性リンパ腫cutaneous T-cell lymphoma，おもに 菌状息肉腫mycosis fungoidesの治療が含まれる．特に 全身に拡大した菌状息肉腫の治療には，医療用直線加 速器を用いた電子線の全身照射が有効である1２．
利用する電子線のエネルギーは，深部方向への皮屏 浸潤の度合いによって決定されるが，全身照射では利 用線錐中心に扔いておもに平均入射エネルギーで3〜 4MeVである1).

電子線の全身照射が紹介された1950售代前半から現 在まで，幾つかの照射方法が用いられてきた，最近で は照射の均一性の面から, Karzmarkが紹介し，後に

\title{
Measurement of the Mean Energy of the Off-axis Incident Electron without the Beam Guide: Using a Scintillating Fiber Beam-Energy Monitor for Elec- tron Beam Therapy
}

\author{
YUICHI AOYAMA and SHUJI KOYAMA') \\ Department of Radiology. Nagoya University Hospital \\ 1 ) Department of Radiological Technology. School of Health Sciences, Nagoya University \\ Received Jan. 10, 2002; Revision accepted Apri1 30, 2002; Code No. 853
}

\section{Summary}

In the case of total skin electron therapy without the beam guide, the electron beam is scattered just outside the gantry exit, dose uniformity in the field is broken, and dose is spread outside the light field. The aims of this study were to measure the mean energy of the off-axis incident electron beam without the beam guide and to establish a reference for the clinical situation. For the measurement, a $4 \mathrm{MeV}$ electron beam was selected among several energies from the linear accelerator. A scintillating fiber beam energy monitor measured the mean energy of the incident electron beam. This energy monitor is a small, light-weight piece of equipment composed of a wedge absorber, scintillation fiber, and photodiode. We found the relationship between electron energy and the indicated value of the energy monitor by means of the estimation of correction factors for five different kinds of electron energy. The preferable linear correlation of 0.997 of the coefficient of determination $\left(R^{2}\right)$ was obtained. From the results of measurement at each point, those variations due to the off-axial distance were about $5 \%$ within the measured area. It was assumed that the energy did not change rapidly beyond the light field. Clinically, this amount of variation in energy may not cause any problem.

Key words: Electron beam, Scintillating fiber, Energy monitor, Off-axis, Total skin electron 
Pageが改良を加えた前面 3 方向，後面 3 方向，計 6 方 向の一般にStanford法と呼ばれる照射が最適であると されている3，4).多くの放射線治療施設では十分な治 療距離が得られないため, Stanford法の照射を行う場 合の各方向の照射は，Fig. 1のように放射線治療装置 のガントリ角度を変化させた 2 回の照射の合成で成立 する事となる3).

高エネルギーの電子線は，放射線治療装置の照射口 から照射された後，散乱し徐々にその分布をガウス分 布に近づける5)。 そのため通常の電子線治療において は，アプリケータを用いて病䉓面に均一な電子線の照 射を可能とする。しかし電子線の全身照射の場合では 前述のごとく，距離が離れるために通常このアプリケ 一夕を用いてもその用を成さない。そのため，前述の 2 回の照射で 1 方向の治療を行う場合，二つの照射野 の位置関係が大きな問題となる.

高エネルギー電子線およびX線の治療においては, 二つの照射野を結合する場合，皮初面に映し出された 光照射野を参考にそれらの位置関係を決定することが 多いが，アプリケータを用いない高エネルギー電子線 治療の場合には，電子線の散乱のために光照射野外で も電子線が計測される，そのため近接するはずの二つ の光照射野端は，最適な線量プロファイルを得るには かなり離れた位置を取ることになる。

また，通常の電子線照射においてはアプリケータ を利用するため，アプリケータをつけた状態での平 均入射エネルギーを利用している。電子線の全身照 射については，これまでAAPM (American Association of Physicists in Medicine) $)^{6}$ などからその治療方法や測 定技術が報告また推奖されている．しかしそのなか では，アプリケー夕を装着せずまた線量強度が軸外 方向へ変化する場合での電子線の平均入射エネルギ 一についての報告は見受けられない。この研究で は，アプリケータを用いない場合の軸外平均入射工 ネルギーの測定を行い，臨床の指標とすることを目 的とする。

\section{1. 方 法}

この研究は緒言に述べたごとく，アプリケータを用 いない場合での笪子線平均入射エネルギーに対する基 碟的な研究である。そのため, 各测定点はVarian Medical System社製矤療用直線加速器Clinac 2100Cの アイソセンタ $(\mathrm{SAD} 100 \mathrm{~cm})$ を通り，コリメータ軸と電 子の加速方向に直交する線上のみとした。（Fig. 2)

まずアイソセンタから距離が離れるにしたがって, 電子線の線量強度が変化するのを確認した後，これと 同じ点での電子線エネルギーの測定を行った．また使 用する電子線のエネルギーは，X線の混入を避けるた
めMixDpやポリスチレンなどのエネルギー減衰板degraderを用いず, 直線加速器本体で選択可能な $4 \mathrm{MeV}$ を使用した，線量率は測定装置の感度を踏まえ低線是 域まで測定するという前提で，装置の最大線员率 400MU (monitor units)/minを用いた。

通常，電子線の測定はSSD (source surface distance) $100 \mathrm{~cm}$ で行われるが, 本研究のなかでは測定器の位置 を明確にするため，また電子線線量強度を相対電離㽞 で表すことを踏まえ，あえてピーク深までの距離を無 視LSAD (source axis distance) $100 \mathrm{~cm} に て$ 測定を行っ た.

\section{1-1 電子線線量強度の確認}

電子線線量強度の測定は，応用技研製Japanese Association of Radiological Physics (以下, JARP)形線足 計C-110および同社の電位計AE-134a とMixDpファン トムを用いた。JARP形線量計は同じ測定系で確認済 みの，アプリケータを使用した場合のビーム中心軸 上のピーク深であるファントム表面からの深さ $7 \mathrm{~mm}$ に測定中心を設置した．測定方法の詳細に関しては 可能な限り，日本医学放射線学会物理部会が推奖し ている吸収線量の標準測定法に準じた7)。通常, 電子 線の平均エネルギーが10 MeV以下ではシャロー型線 量計が用いられるが，ビームが斜入射するような場 合には線量計の方向依存性の問題が生じてくる。そ のため今回の研究では，あえてJARP形線量計を用い 絶対值測定をせずに相対值で表現した，照射野はア プリケータを用いず，装置の上下絞りのみで設定可 能な最大照射野 $40 \times 40 \mathrm{~cm}^{2}$ とし, 测定は電于の加速と 直交する方向(transverse方向)としたままた，その工 ネルギーを推定する軸外距離の範囲は光照射野より も広く, 最大線量との比における約 $5 \%$ の位置まで 行った.

\section{1-2 電子線エネルギーの測定}

電子線平均入射エネルギーの測定には青山らが製作 したシンチレーションファイバ電子線エネルギーモニ

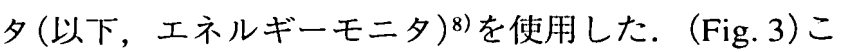
のエネルギーモニタは，楔型吸収体とシンチレーショ ンファイバ，フォトダイオードを組み合わせたコンパ クトなものである。しかし，基本的には直線加速器の エネルギー管理のための測定器であり，感度幅と方向 依存性がある。そのため，事前に方向依存性に対する 確認を行った後, 各位置での平均入射エネルギーを測 定した。

方向依存性については一辺 $15 \mathrm{~cm}$ の矩形照射野アプ リケータを用い，エネルギーモニ夕に対する照射触 を変化させて確認した，照射角度は，エネルギーモニ 


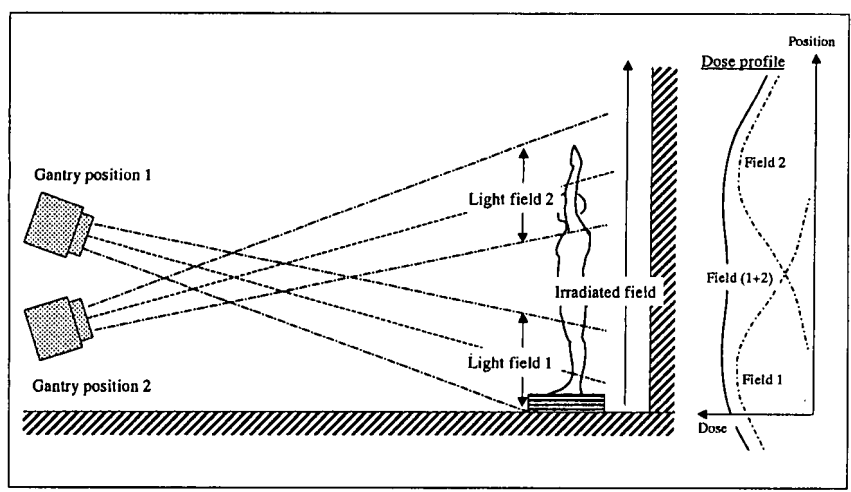

Fig. 1 Geometrical position of the symmetrical dual-field irradiation technique and difference between two light fields and the irradiated field.

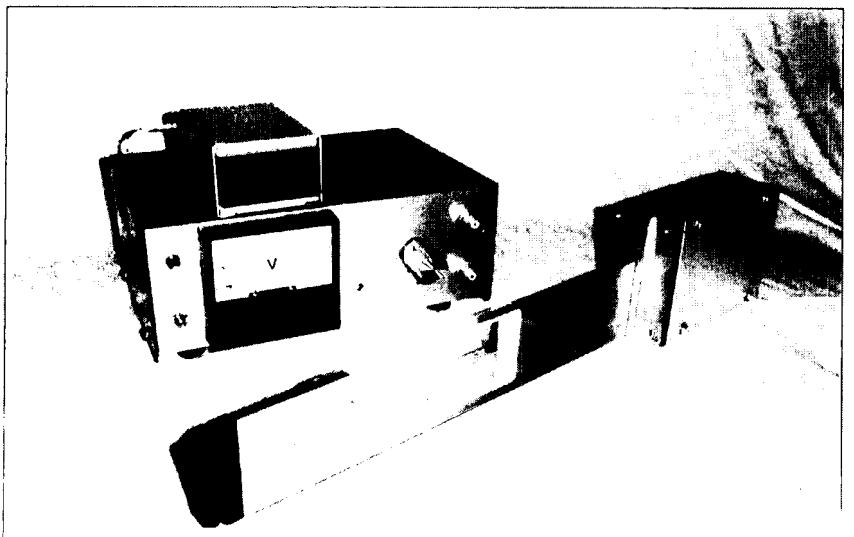

Fig. 3 A scintillating fiber beam energy monitor system for electron beam.

夕検出部の 2 本のシンチレーションファイバを結び, 楔吸収体の開口中心を通る測定中心軸と, 電子線ビー ムの中心軸とが作り出す角度で規定した，実際の測定 では，線源に近いシンチレーションファイバの長軸を 中心に，楔吸収体の面を傾けることで角度を変化させ た。

平均入射エネルギーの測定では，光照射野内にあ っては，エネルギーモニタ検出部の測定中心軸が常 に電子線ビームの実効線源を向くよう，方向依存性 の確認と同様にエネルギーモニタ検出部の楔吸収体 面を傾けて設置した．また光照射外にあっては，実 効線源ではなくガントリ・ヘッドの照射口近位端にエ ネルギーモニタ検出部の測定中心軸を向けて測定を 行った。

このエネルギーモニタを使用するにあたっては，基 準となる電子線エネルギーとモニタ読み值との関係 (校正係数)が必要であるため, 先に直線加速器により 照射可能なすでにその值が判明している5 種のエネル ギーの電子線を利用し校正を行った。これらの校正に 利用した電子線エネルギーの決定についても，日本医

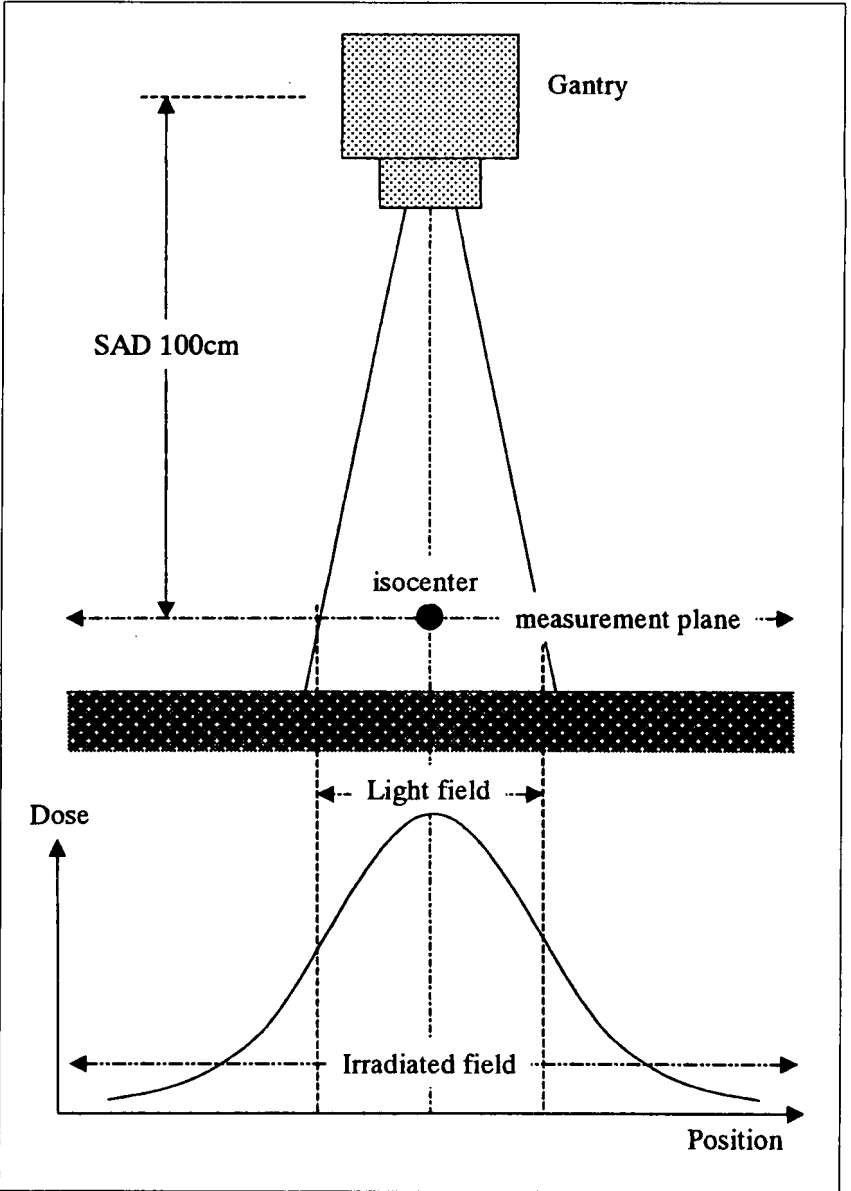

Fig. 2 Geometrical difference between the effective irradiated field and light field.

学放射線学:会物理部会が推奨している吸収線量の標準 測定法に準じて行った7).

\section{2. 結 果}

\section{2-1 電子線線量強度の確認}

ビームプロファイルは，左右対称であると仮定し て，アイソセンタから片側データのみ示してある.

Table 1およびFig. 4を見ると, 光照射野端はアイソセ ンタからの軸外距離 $20 \mathrm{~cm}$ であることから，電子線が 散乱したことでビームプロファイルがガウス分布様を 旺していることが確認できる.

\section{2-2 電子線エネルギーの測定}

まずエネルギーモニタの方向依存性を確認するた め，電子線ビームのエネルギーモニ夕に対する照射角 度を変化させて測定を行った. Fig. 5に示されるごと く，エネルギーモニタの指示值は設置角度の誤差が10 度を超えると大きく変動した。この結果を踏まえ各測 定位置での設置では，基準設置角より角度を \pm 5 度変 化させて值が変動しないかを確認したが，変化は見ら 
Table 1 Change in relative ionization values with off-axis distance at depths of $7 \mathrm{~mm}$ and $5 \mathrm{~mm}$ in the phantom

\begin{tabular}{|c|c|c|}
\hline \multirow{2}{*}{$\begin{array}{l}\text { off-axis distance } \\
(\mathrm{cm})\end{array}$} & \multicolumn{2}{|c|}{ relative ionization value $\%$} \\
\hline & depth: $7 \mathrm{~mm}$ & depth: $5 \mathrm{~mm}$ \\
\hline 0 & 100.0 & - \\
\hline 2 & 99.8 & - \\
\hline 4 & 99.0 & - \\
\hline 6 & 97.7 & - \\
\hline 8 & 95.9 & - \\
\hline 10 & 93.6 & - \\
\hline 12 & 90.4 & - \\
\hline 14 & 85.8 & - \\
\hline 16 & 80.5 & 79.6 \\
\hline 18 & 71.8 & 71.5 \\
\hline 19 & 67.8 & 66.9 \\
\hline 20 & 60.6 & 62.1 \\
\hline 21 & 53.4 & 55.8 \\
\hline 22 & 47.5 & 46.7 \\
\hline 23 & 38.8 & 39.1 \\
\hline 24 & 30.4 & 33.0 \\
\hline 25 & 24.1 & 25.8 \\
\hline 26 & 19.4 & 19.5 \\
\hline 27 & 13.6 & 15.0 \\
\hline 28 & 10.4 & 11.2 \\
\hline 29 & 7.3 & 8.3 \\
\hline 30 & 5.7 & 6.3 \\
\hline 31 & 4.2 & 4.9 \\
\hline 32 & 3.4 & 3.8 \\
\hline 33 & 2.5 & 3.0 \\
\hline
\end{tabular}

れなかった，次に校正のために，装置から出力可能な 5 種類の電子線エネルギーの測定を行った。結果よ ク，電子線エネルギーと読み值との関係をFig. 6にあ る一次の関数で表した．単純な直線近似ではあるが， 決定係数 R 2 乗は0.997とよく相関している.ささらに この関数を用いて電子線エネルギーを求め, 先ほどの 電子線線量強度の測定と同様に，軸外位置における電 子線エネルギーの值をTable 2およびFig. 7に示す. エ ネルギーモニタの感度限界のため, 軸外距離 $26 \mathrm{~cm}$ を 超えて測定することは不可能であった.アイソセンタ 平面内の利用線錐中心の電子線エネルギーは $3.66 \mathrm{MeV}$, 対して測定可能な最外側 $26 \mathrm{~cm}$ では $3.47 \mathrm{MeV}$ 約 $5 \%$ 低い值となった。

\section{3. 若 察}

シンチレーションファイバ方式の電子線エネルギー モニタ検出部の構造を, Fig. 8に示す．検出部は，銅 板をV字形に切り取って作った吸収体と、これを上下 から平行に挟み込む一対のシンチレーションファイバ

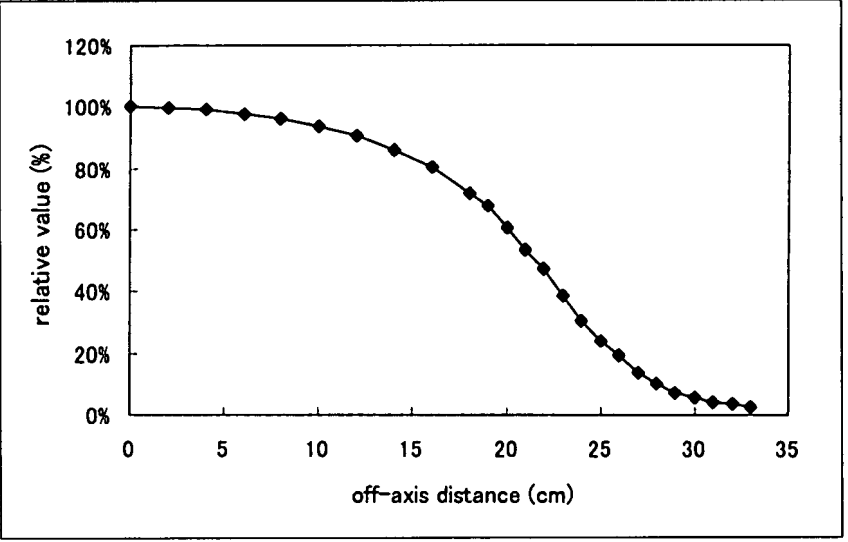

Fig. 4 Change in relative ionization values with off-axis distance at a depth of $7 \mathrm{~mm}$ in the phantom.

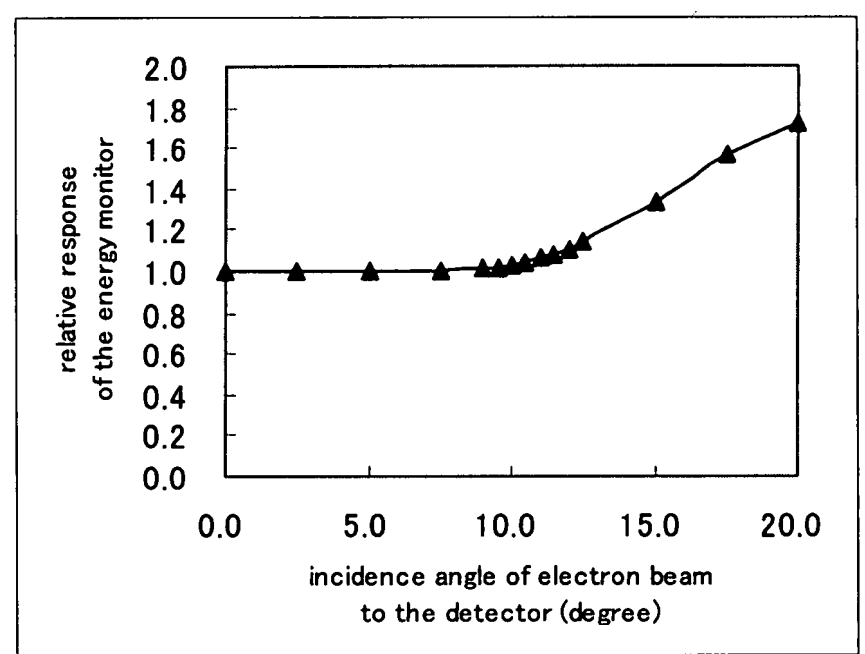

Fig. 5 Change in the response of the scintillating fiberenergy monitor with an incident angle of the electron beam to the energy monitor.

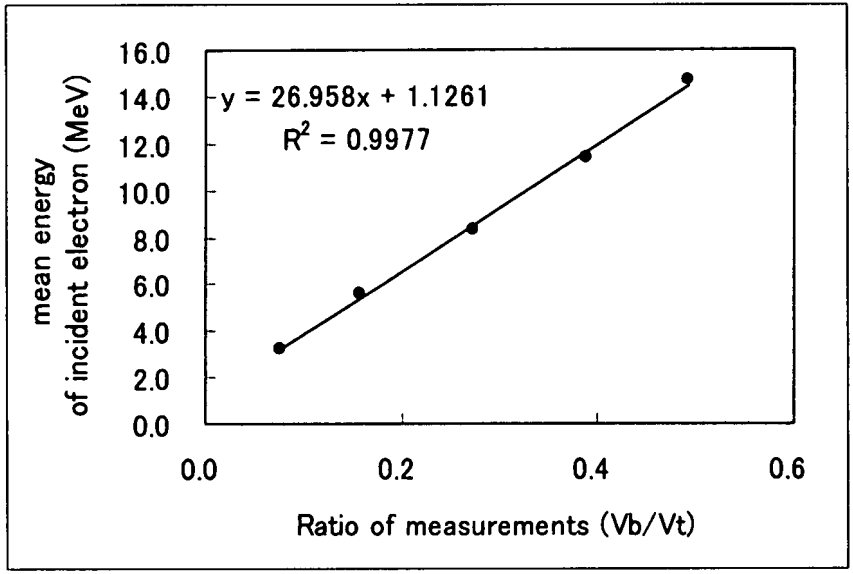

Fig. 6 Correlations between mean energy of the incident electron beam and measured value of the energy monitor as a ratio of output voltage from the bottom fiber $(V b)$ to that from the top fiber $(V t)$.

（直径約 $1 \mathrm{~mm}$ ) から構成されている。電子線がシンチ レーションファイバに照射されると,ファイバが発光 する．上側のファイバは，吸収体のV字部のみに電子 線が照射されるように，他の部分を銅板で覆って遮蔽 
Table 2 Variation in incident energy of electron beam with off-axis distance. Measurements were made by scintillating fiber beam energy monitor. Because of the low sensitivity of the monitor system, measurements were obtained at an off-axis distance greater than $27 \mathrm{~cm}$.

\begin{tabular}{cccc}
\hline $\begin{array}{c}\text { off-axis distance } \\
(\mathrm{cm})\end{array}$ & $\begin{array}{c}\text { estimates of } \mathrm{E}_{0} \\
(\mathrm{MeV})\end{array}$ & Mean of $\mathrm{Vb} / \mathrm{Vt}$ & $\begin{array}{c}\mathrm{Vt} \\
\text { (volts) }\end{array}$ \\
\hline 0 & 3.66 & 0.094 & 4.47 \\
2 & 3.66 & 0.094 & 4.47 \\
4 & 3.66 & 0.094 & 4.38 \\
6 & 3.66 & 0.094 & 4.35 \\
8 & 3.63 & 0.093 & 4.30 \\
10 & 3.66 & 0.094 & 4.21 \\
12 & 3.63 & 0.093 & 4.03 \\
14 & 3.63 & 0.093 & 3.84 \\
16 & 3.61 & 0.092 & 3.58 \\
18 & 3.58 & 0.091 & 3.26 \\
19 & 3.58 & 0.091 & 2.97 \\
20 & 3.58 & 0.091 & 2.64 \\
21 & 3.55 & 0.090 & 2.34 \\
22 & 3.55 & 0.090 & 2.11 \\
23 & 3.50 & 0.088 & 1.64 \\
24 & 3.50 & 0.088 & 1.47 \\
25 & 3.47 & 0.087 & 1.02 \\
26 & 3.47 & 0.087 & 0.85 \\
27 & $*$ & $*$ & 0.54 \\
28 & $*$ & $*$ & $*$ \\
\hline & & & \\
\hline & & & \\
\hline
\end{tabular}

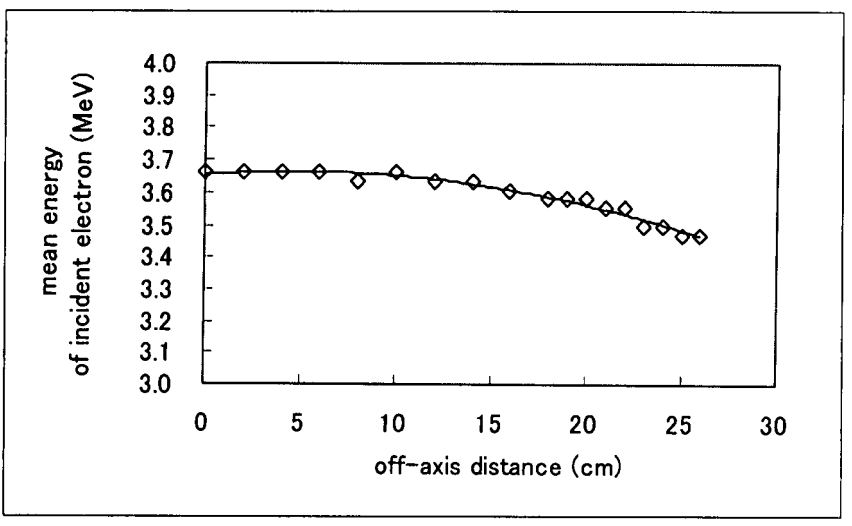

Fig. 7 Change in the mean incident energy of the electron beam according to off-axis distance. Mean energy was estimated by the regression equation in Fig. 6 .

してある、いま，電子線をV字全体に照射すると，中 央部の電子が吸収体を通過できる笵囲だけが照射され 下側のファイバには発光する。この範囲は, 電子線エ ネルギーとともに拡大し発光量が増大する. 発光量 は，奏際にはフォトダイオードで電気信号に変換され 電圧として観測される。この下側ファイバの発光量に したがった発光ダイオードからの電圧Vb (Volts)を電 于線照射強度について規格化するため吸収体透過前の

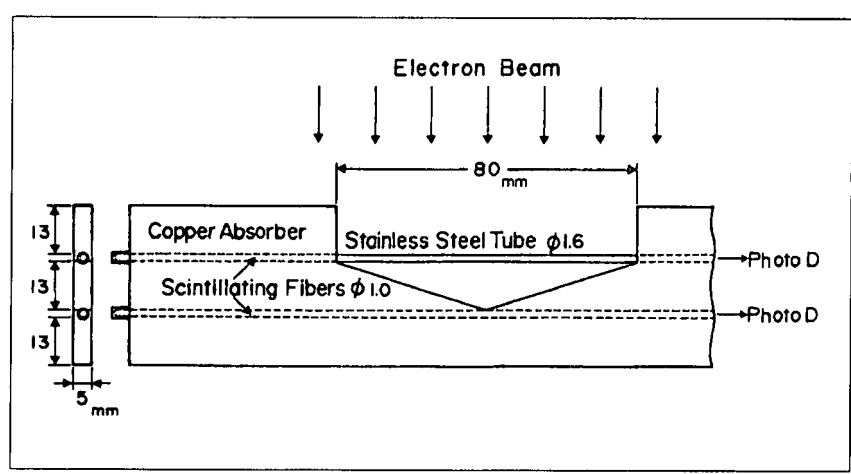

Fig. 8 Schematic diagram of a scintillating fiber type of beam-energy measuring device.

上側ファイバからの発光量による電圧 $\mathrm{Vt}($ Volts $)$ 基 準にとりこれとの比 $\mathrm{Vb} / \mathrm{Vt}$ をナログ割算器で求める と電子線エネルギーに依存する量が得られる8).

Fig. 9 とFig. 10にアナログ割算器の電気的特性を示 す。分母部電圧 $\mathrm{Vt}$ を一定にして，分子部電圧 $\mathrm{Vb}$ を変 化させると，Fig.9の様になる。これより，電压Vbと 読み值の出力 $\mathrm{Vb} / \mathrm{Vt}$ は, 原点 0 から直線的な比例関係 にあることが分かる，次に，読み值の出力 $\mathrm{Vb} / \mathrm{Vt}$ を一 


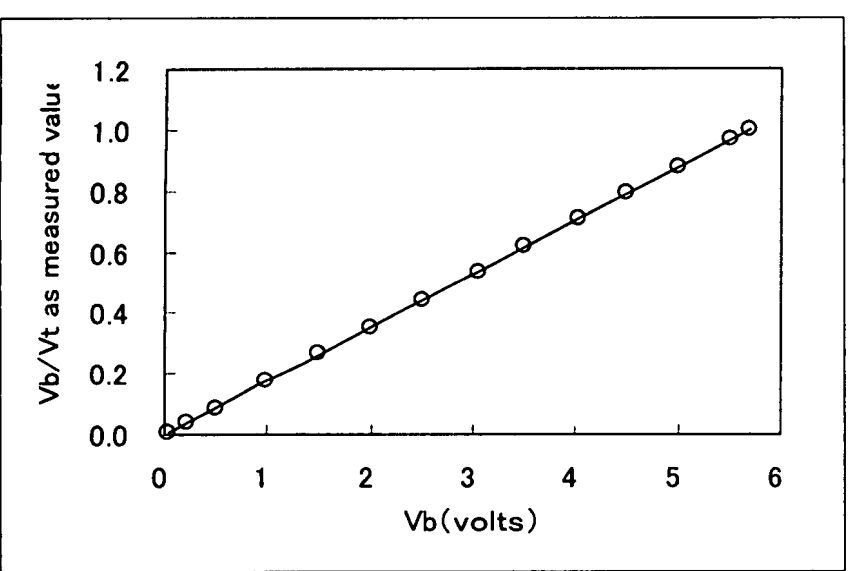

Fig. 9 Electric characteristics of the scintillating fiber beam energy monitor. The response $\mathrm{Vb} / \mathrm{Vt}$ obtained by a dividing circuit in the beam monitor system is linear as function of $\mathrm{Vb}$ value.

定に保って電圧Vtを変化させると，Fig. 10のようにな

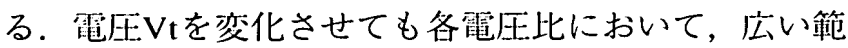
囲で一定の直線部分がある事が分かる．ただし，電圧 $\mathrm{Vt}$ が 1.0V未満になると急激にこの比が減少するた め, 娈み值の信頼性がなくなる。つまり，上側ファイ バの発光量にしたがった電圧 Vtの出力が約 IV未満で は，測定不可能となることが予想される．

Table 2の電子線のエネルギー分布を見ると軸外距離 $26 \mathrm{~cm}$ ではVtの電圧は0.85 voltsであり，このあたりか ら信頼性が低く，実際に26cmを超えると明らかに值 の変動が激しくなったため測定不可能と判断した。 ち なみに軸外距離 $26 \mathrm{~cm}$ の位置での線量率は，アイソセ ンタでの線量率の約20\%である。

軸外距離に対する電子線線量強度分布はFig. 2のよ うにガウス分布を呈する。ここで改めて光照射野の開 度と比較すると, 光照射野の端であるはずの軸外距離 $20 \mathrm{~cm}$ では，未だ電子線線量強度約 $60 \%$ を保ってい る。このことより，放射線治療の臨床において，アプ リケータなしでの治療時にはオーバラップが起きるた め，単純に光照射野の端で二つの照射野を結合しては いけないことが確認できる。この場合のオーバラップ は，結合部における過線量域を作り出す，そのため実 際の臨床では，二つの光照射野の間にはかなりの空間 が必要となるので，最終的には治療照射野内の線量分 布確認が必要である，放射線治療においては，その不 確定性を $5 \%$ 以下に押さえるように勧告されている が，電子線の全身照射では，この値を確保することは 非常に困難である。均一性のみを注目した場合でも， 10\%程度の報告しかみうけられない4)。しかし，患者 の全身を包み込むほどの目大なアプリケータを利用す れば，改善は可能である9".

軸外距離による電子線エネルギーの変動は, アイソ センタ平面 $(\mathrm{SAD} 100 \mathrm{~cm}$ )の軸外距離 $26 \mathrm{~cm}$ 以内で約 $5 \%$

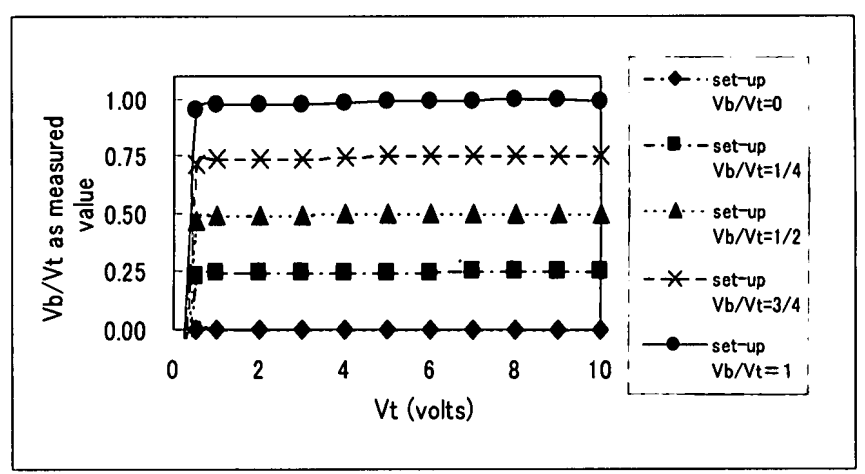

Fig. 10 Electric characteristic of the scintillating fiber beam energy monitor. The responses of $\mathrm{Vb} / \mathrm{Vt}$ as measured value by a dividing circuit according to Vt value.

である。この程度のエネルギーの変化は，臨床におい て問題となるものではない，吸収線星変換係数で考え ると $1 \%$ 程度の変動でしかない. 特に問題となるのは ビームの幾何学的な入射方向で，入射伯度によってピ 一ク深の位置が変動することが予想され，そのため線 量の過小評価や過大評価を招く可能性がある. Table 1 には $7 \mathrm{~mm}$ 深の值と並べ，参考值として $5 \mathrm{~mm}$ 深の值が 示してあるが，予想されたごとく軸外距離 $24 \mathrm{~cm}$ 以上. では $5 \mathrm{~mm}$ 深の值が逆に高くなっている。二つの照射 野を結合して電子線全身照射の一方向を作り出す場合 には，幾何学的な位置関係よりピーク深の位置を部算 にて子測する必要がある。

低エネルギーの電子線での吸収線显の測定には，通 常シャロー型線量計を朋いるが，ビームが斜入射する ような場合には線量計の方向依存性の問題が生じてく る.そのため今回の研究では，あえてJARP形線员計 を用い絶対值測定をせずに相対值で表現した。どのよ うな方法で吸収線量を求めるかは，電子線全身照射に おける今後確立すべき問題の一つであると思われる。

今回使用したエネルギーモニタは小型軽星で，多点 を測定するには有效であった。しかしこの実験で使用 するにあたっては感度幅が十分ではなく，そのため低 線量率域でのエネルギー測定は諦めざるをえなかっ た.

電子線のエネルギーは光照射野を超えた範囲であっ ても，急激な変化はないと推測される。しかし，この 方向内での線量の均一性をよくし，またこれと直交す る放射方向の均一性をよくするには，特殊なアプリケ 一夕を用いるなどの対応が必要である。

今回用いた公称 $4 \mathrm{MeV}$ 電子線のアプリケータを朋い た場合での垁際の平均入射エネルギーは, MixDpファ ントムとシャロー型線量計を用いて測定すると $3.26 \mathrm{MeV}$ であり, 対してシンチレーションファイバ婜 
子線エネルギーモニタで測定したアプリケータがない 場合の平均入射エネルギーは3.66MeVとなり，約 $10 \%$ の差があった。そのため，アプリケータの有無による 平均入射エネルギーの違いを日本医学放射線学会物理 部会の吸収線量の標準測定法7にしたがってファント ム実験で確認したところ，ファントム実験での双方の 值の間にはほとんど差が見られなかった．前述の約 10 \%の涳の原因は，基本的に電子線エネルギーの校正用 であるエネルギーモニタの検任部またはデー夕処理部 へのX線の混入の影響ではないかと考えられる.

\section{4. 結 語}

アイソセンタ平面内のコリメータ回転軸_上の電子線 エネルギーは3.66MeVであるが，調べた最大軸外距離 $26 \mathrm{~cm}$ では3.47MeVと約 $5 \%$ 低い值となった。この程 度のエネルギーの変化は, 阽床において問題となるも のではない. また，アプリケータを用いない場合での 電子線のエネルギーは, 光照射野を超えた範囲であっ
ても急激な変化はないと推測できる。

今回使用したシンチレーションファイバ電子線エネ ルギーモニタは，小型軽量で，この研究のように多点 を測定するには有効であった。しかし，このエネルギ 一モニ夕を実験で使用するなかで，感度や方向依存性 の問題が指摘された。

正確な線量評価に当たっては，ビームの入射觕度に 対する十分な検討が必要である。

\section{謝 辞}

この研究を行うにあたり，シンチレーションファイ バ電子線エネルギーモニタ利用を快くご了承いただ き，またその基礎データ使用の許可を下さった名古屋 大学医学部保健学科の青山隆彦教授, またご協力いた だきました諸先生方に深く感謝いたします。

なお，この論文の主旨は第55回総会学術大会で報告 しました。

\section{参考文献}

1) Eric CV, Bizhan M: Principles and Practice of Radiation Oncology Second Edition, J.B.Lippincott co.: 503-510

2) 難波鉱二：病理，放射線医学体系33.161,(1985).

3) Karzmark CJ, Loevinger R, Steele RE, et al.: A technique for large field superficial electron therapy. Radiology 74, 633644, (1960).

4) Page V, Gardner A, and Karzmark CJ: Patient dosimetry in the electron treatment of large superficial lesions. Radiology 94, 635-641, (1970).

5) Holt JG, Perry DJ: Some physical considerations in whole skin electron beam therapy, Med. Phys. 9,769-776, (1982).
6) AAPM: Total skin electron therapy, Technique and dosimetry, AAPM report 23, USA, (1987).

7) 日本医学放射線学会物理部会編：放射線治療における高工 ネルギーX線および電子線の吸収線量の標準测定法: 通商应 業研究社, 日本, (1986).

8) Aoyama T, Maekoshi H, Tsuzaka M, et al.: A scintillating fiber beam-energy monitor for electron beam therapy, Med. Phys. 22, 2101-2102, (1995).

9）川添悦代，袋野和義，鬼塚昌彦，他：急性単球製白血病の 皮同浸潤に対する電子線全身照射の 1 例，日本医放会誌51 (2), 48-53,(1991)

Fig. 12 門の合成で 1 万向の電子線照射を行う場合の幾何学的配置図、光照射野と笑照射野の位置関係

Fig. 2 光照射野と実照射野の幾何学的関係

Fig. 3 シンチレーションファイバ電子線エネルギーモニタ

Fig. 4 ファントム $7 \mathrm{~mm}$ 深における相対電離量の軸外方向への变化

Fig. 5 シンチレーションファイバ電子線エネルギーモニタへの電子線の入射角度に対する測定值の変化

Fig. 6 電子線平均入射エネルギーとエネルギーモニタの読み值との校正係数、この読み值は下部ファイバの出力電圧Vbを上部ファ イバの出力電王 $\mathrm{Vt}$ で規格化している

Fig. 7 Fig. 6の校正係数を基に求めた軸外方向への電子線平均入射エネルギーの変化

Fig. 8 シンチレーションファイバ電子線エネルギーモニタの検出部棈造

Fig. 9 シンチレーションファイバ雪子線エネルギーモニタの電気的特性, $\mathrm{Vb}$ 変化させた場合の割算器からの出力Vb/Vtの直線 的な応答性

Fig. 10 シンチレーションファイバ電子線エネルギーモニタの電気的特性, $\mathrm{Vt}$ t変化させた場合の割算器からの出打 Vb/Vtの応答性

Table 1 ファントム深 $7 \mathrm{~mm}$ と $5 \mathrm{~mm}$ において電離箱線量計で測定した軸外方向への電離量の変化

Table 2 シンチレーションファイバ電子線エネルギーモニタで測定した軸外方向への電子線平均入射エネルギーの変化、電子線エ ネルギーモニタの感度限界から $27 \mathrm{~cm}$ 以_上の軸外距離では測定不可能である 